\title{
A SZERFOGYASZTÁS RIZIKÓTÉNYEZŐI KÖZÉPISKOLÁSOK KÖRÉBEN
}

\author{
ELEKES ZSUZSANNA
}

Budapesti Corvinus Egyetem Szociológia és Társadalompolitika Intézet

\begin{abstract}
A tanulmány első része a középiskolában tanuló fiatalok dohányzási, alkohol- és egyéb drogfogyasztási szokásaiban bekövetkezett hosszú távú változásokat elemzi az ESPAD (European School Survey Project on Alcohol and Other Drugs) 1995-2015 közötti időszakra vonatkozó adatai alapján, nemzetközi összehasonlításban. Ezt követően azt vizsgáljuk, hogy a főbb társadalmi-demográfiai tényezők (nem, iskola típusa, székhelye, szülők iskolai végzettsége, család típusa) mennyire befolyásolja a fiatalok fogyasztási szokásait és a veszélyesebb fogyasztási formák kialakulását. Végül néhány egyéb veszélyeztető/védő-óvó tényező (szabadidő, baráti és családi integráltság) és a szerfogyasztás kapcsolatát vizsgáljuk.
\end{abstract}

Kulcsszavak: középiskolások, szerfogyasztás, trendek, rizikótényezők, társadalmi különbségek

The paper presents the long-run changes in tobacco, alcohol and other drug use of secondary school children based on the ESPAD surveys (European School Survey Project on Alcohol and Other Drugs) between 1995-2015 in international comparison. The second part of the paper discusses the effects of different socio-demographic factors (gender, school type settlement of school, parent's education level and family structure). Finally, we examine the effects of other risk and protective factors (leisure time activities, family and peer-group integration) on substance use of the young.

Keywords: secondary school, substance use, trends, risk factors, social differences

\section{Bevezetés}

z ESPAD program (European School Survey Project on Alcohol and other
Drugs) 1995-ben indult azzal a céllal, hogy 4 évente rendszeresen ismétlődően
idöben és nemzetközileg összehasonlítható adatokat gyüjtsön középiskolában

Levelező szerző: Elekes Zsuzsanna, Budapesti Corvinus Egyetem Szociológia és Társadalompolitika Intézet, 1093 Budapest, Közraktár u.4-6. E-mail: zsuzsanna.elekes@uni-corvinus.hu 
tanuló 16 éves fiatalok szerfogyasztási szokásairól, az azokban bekövetkezett változásokról. Eddig hat adatfelvételre került sor, és 2019-ben zajlik a hetedik adatfelvétel. A program változó számban 30-35 európai ország közremüködésével zajlik, és 25 olyan európai ország van (köztük Magyarország is), amely eddig valamennyi adatfelvételben részt vett és így immár egy 20 évet átölelő időszakra vonatkozóan rendelkezik információkkal a főbb szerfogyasztási formák alakulásáról (Hibell et al. 2012; The ESPAD Group 2016).

$\mathrm{A} z$ adatfelvételek az adott évben 16 évesek országos reprezentatív mintáján készülnek önkitöltős módszerrel, osztályos lekérdezéssel, országonként átlagosan 2400 fős nettó mintán. Az osztályos lekérdezés következtében Magyarországon azok a középiskolai évfolyamok kerülnek be a mintába, ahol a 16 évesek az adatfelvétel idején a legnagyobb arányban tanulnak. Így 2015-ben a 9-10. évfolyamosok országos reprezentatív mintáját vizsgáltuk (teljes nettó minta: 6660 fö).

A következőkben először a hazai, középiskolában tanuló fiatalok dohányzási, alkoholés egyéb drogfogyasztási szokásaiban bekövetkezett hosszú távú változásokat mutatjuk be az 1995-2015 közötti időszakra vonatkozóan, nemzetközi összehasonlításban. Ezt követően a 2015. évi adatok alapján azt vizsgáljuk, hogy a föbb társadalmi-demográfiai tényezők (iskola típusa, székhelye, szülők iskolai végzettsége, család típusa) mennyire befolyásolják a fiatalok fogyasztási szokásait és a veszélyesebb fogyasztási formák kialakulását. Bemutatjuk, hogy a különböző veszélyeztető és védő-óvó tényezők (szabadidő, baráti és családi integráltság) milyen kapcsolatban állnak a szerfogyasztással.

A trendeket a nemzetközi elemzésekben is részt vevő 16 éves középiskolások mintáján vizsgáljuk. A társadalmi tényezők hatását a 2015. évi adatfelvételben részt vett valamenynyi 9-10. évfolyamos diák adatai alapján mutatjuk be.

\section{Trendek}

\section{Dohányzás}

Az ESPAD-kutatások valamennyi adatfelvételében részt vevő országok adatai alapján a dohányzást valaha kipróbálók aránya 1995 és 1999 között stabil volt, majd először lassabb, az utóbbi években pedig egyre határozottabb ütemben csökkent. Az előző hónapban és a napi rendszerességgel dohányzók aránya a 90-es években szintén nőtt, 1999-et követően azonban ezek a mutatók is határozottan javulni kezdtek, azaz a dohányzás minden mutatója mérséklödött 1999 és 2015 között az európai 16 éves, iskolában tanuló fiatalok körében. 2015-ben az európai fiataloknak már 54\%-a soha nem próbálta ki a dohányzást. Figyelemre méltó ugyanakkor, hogy míg a 90-es évek közepén a fiúk körében egyértelmủen elterjedtebb volt a dohányzás, mint a lányok között, mára Európa-szerte eltüntek a dohányzás nemi különbségei (The ESPAD Group 2016).

Magyarországon a kedvezö fordulat valamivel később, 2003 után következett be, és nem is volt folyamatos a javuló tendencia. A 2015. évi adatfelvétel eredményei azt mutatták, hogy az egész 20 éves időszakot tekintve ekkor volt a legalacsonyabb a valaha, az előző hónapban és a napi rendszerességgel dohányzók aránya is.

A javuló tendencia egyaránt megfigyelhető a lányoknál és a fiúknál is. A 2015. évi adatok alapján azonban a 16 éves magyar fiataloknak még mindig 18,3\%-a napi rendszerességgel dohányzik (lányok: 17,4\%, fuúk: 19,1\%), az előző hónapban dohányzók aránya 


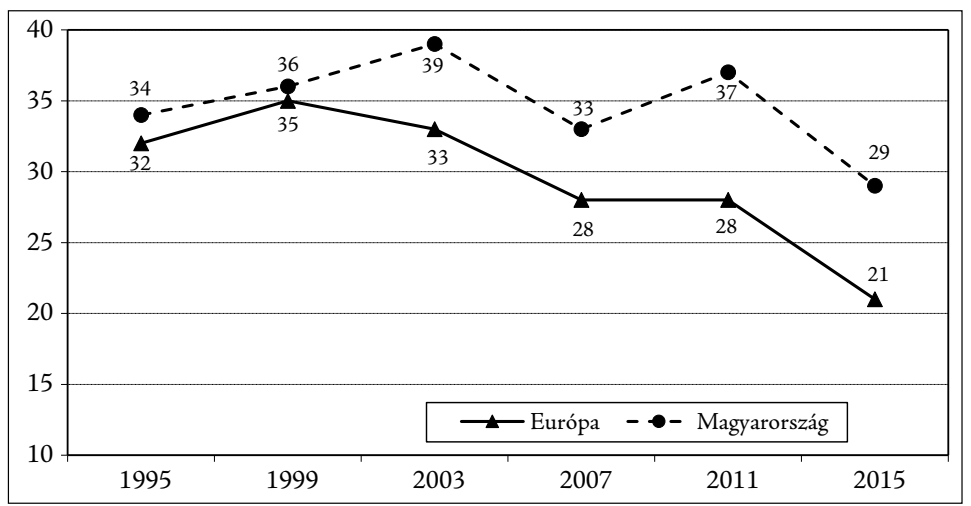

1. ábra: Az előző 30 napban legalább egyszer dohányzók aránya a 16 évesek között Magyarországon és az európai átlag (valamennyi adatfelvételben részt vevő országok adatai)

(Saját szerkesztés The ESPAD Group 2016 alapján)

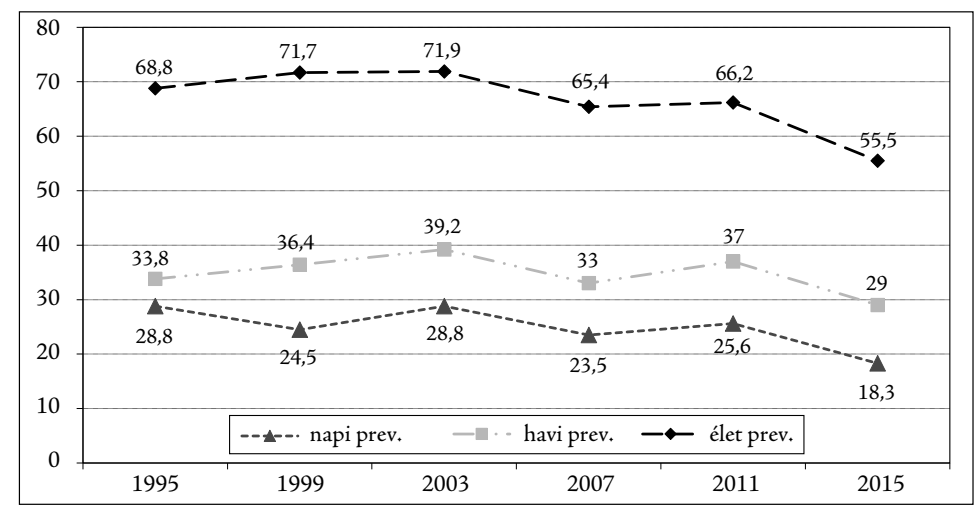

2. ábra: A dohányzás főbb prevalenciaértékeinek változása a 16 éveseknél Magyarországon 1995-2015 között (\%) (Elekes 2016: 24)

pedig 29\% (lányok: 29,9\%, fiúk: 28,2\%). Ez azt jelenti, hogy valamennyi vizsgált mutató alapján a magyar fiatalok körében a dohányzás még mindig jóval meghaladja az európai átlagot (Elekes 2016).

\section{Alkoholfogyasztás}

Az alkoholfogyasztást az ESPAD-kutatás a fogyasztás különböző időszakokra vonatkozó gyakoriságával, az utolsó alkalommal elfogyasztott alkohol mennyiségével, valamint a problémásabb fogyasztást jelző nagyivás ${ }^{1}$ és a lerészegedés gyakoriságával méri.

$\mathrm{A} z$ ESPAD-kutatások valamennyi adatfelvételében részt vevő országok adatai alapján az eddigi életben, illetve a kérdezést megelőző hónapban alkoholt fogyasztók aránya

1 Nagyivásnak a kutatás a legalább öt ital egymás után történő elfogyasztását tekintette, amikor egy ital $5 \mathrm{dl}$ sört vagy $1,5 \mathrm{dl}$ bort vagy fél dl töményt jelentett, azaz a tiszta szesz tartalom alapján közelített a 20 milliliter (16 gramm) standard italhoz. 


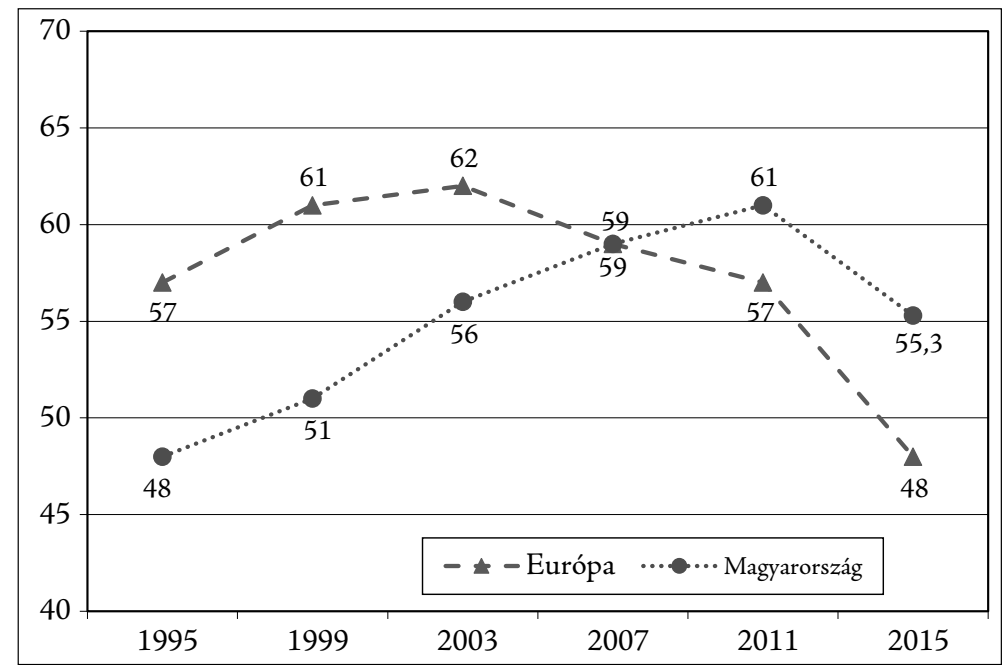

3. ábra: Az előző hónapban alkoholt fogyasztók arányának változása Magyarországon és az európai átlag 1995-2015 (valamennyi adatfelvételben részt vevő országok adatai)

(Saját szerkesztés The ESPAD Group 2016 alapján)

1995-2003 között határozottan nőtt, 2003-at követően pedig - különösen az elöző hónapban alkoholt fogyasztók aránya - jelentösen mérséklödött. A valaha alkoholt fogyasztók aránya a fiúk és a lányok között nem különbözött a 20 év alatt, az előző hónapban alkoholt fogyasztók aránya alapján pedig a korábban sem jelentős fiú-lány különbség eltünni látszik (The ESPAD Group 2016).

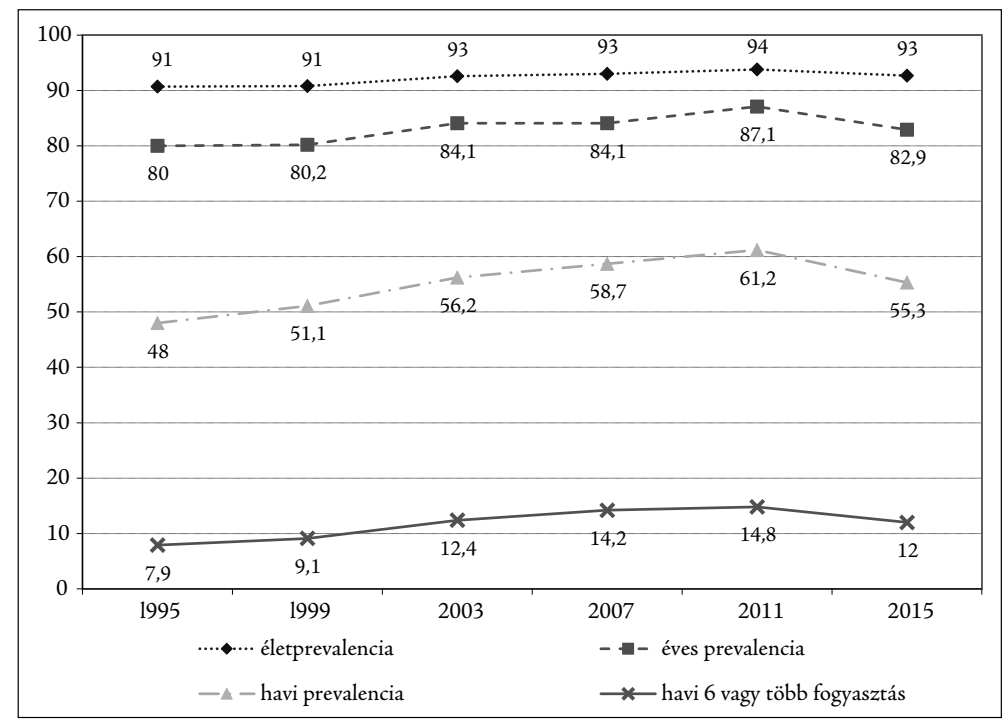

4. ábra: Az alkoholfogyasztás fóbb prevalenciaértékeinek változása a 16 éveseknél Magyarországon 1995-2015 között (\%) (Elekes 2016: 44) 
Magyarországon az alkoholfogyasztás főbb mutatói, eltérően az Európa egészét jellemző trendektől, egészen 2011-ig folyamatosan növekedtek, és csak a 2015. évi adatfelvétel jelezte elöször a trendek megváltozását. Ez azt is eredményezte, hogy míg a kilencvenes években a magyar 16 évesek alkoholfogyasztása - a gyakorisági adatok alapján - még jelentősen elmaradt számos európai társukéhoz képest, addig 2011-ben és 2015-ben az elöző hónapban alkoholt fogyasztók aránya már meghaladta az európai átlagot.

2015-ben a magyar 16 évesek 55,3\%-a fogyasztott valamilyen alkoholtartalmú italt a kérdezést megelőző hónapban, és $12 \%$ legalább hat alkalommal ivott az előző hónapban (Elekes 2016).

Az előző hónapban fogyasztók aránya alapján 1995 és 2007 között a fiúk és a lányok közötti különbségek eltűnni látszottak, de az elmúlt évek javuló tendenciája a lányokat jobban érintette. Így ma a gyakorisági mutatók alapján a lányokra mérsékeltebb alkoholfogyasztás jellemző, mint a fiúkra.

A z utolsó fogyasztási alkalomra vonatkozó mennyiségi adatok alapján kevésbé kedvező tendencia rajzolódik ki a fiatalok által egy alkalommal elfogyasztott alkohol átlagos menynyisége tiszta szeszre átszámolva 2007-töl folyamatosan és határozottan nö Magyarországon. A 2007. évi 50,65 ml/föröl 2015-ben az egy fogyasztó által egy alkalommal elfogyasztott alkohol tiszta szeszre számított mennyisége átlagosan 74,4 $\mathrm{ml} /$ före emelkedett. A növekedés valamennyi italfajtánál megfigyelhető, de a legnagyobb mértékü az alcopopnál ${ }^{2}$ és a tömény italnál volt. Mindez pedig arra utal, hogy a diákok 2015-ben ritkábban fogyasztottak alkobolt, mint a korábbi adatfelvételek során, de amikor ittak, akkor egyszerre sokkal nagyobb mennyiséget, mint amit a korábbi években fogyasztottak.

A fiatalokra különösen jellemző „nagyivás” növekedése Európa-szerte 2007-ig tartott, azaz tovább, mint az alkoholfogyasztás általános terjedése. Az európai átlagot tekintve az elöző hónapban nagyivók aránya 2007-ben volt a legmagasabb, azóta azonban jelentös mérséklödés következett be. A 2015. évi prevalenciaérték megegyezik az időszak kezdetét jelentő 1995. évi értékkel.

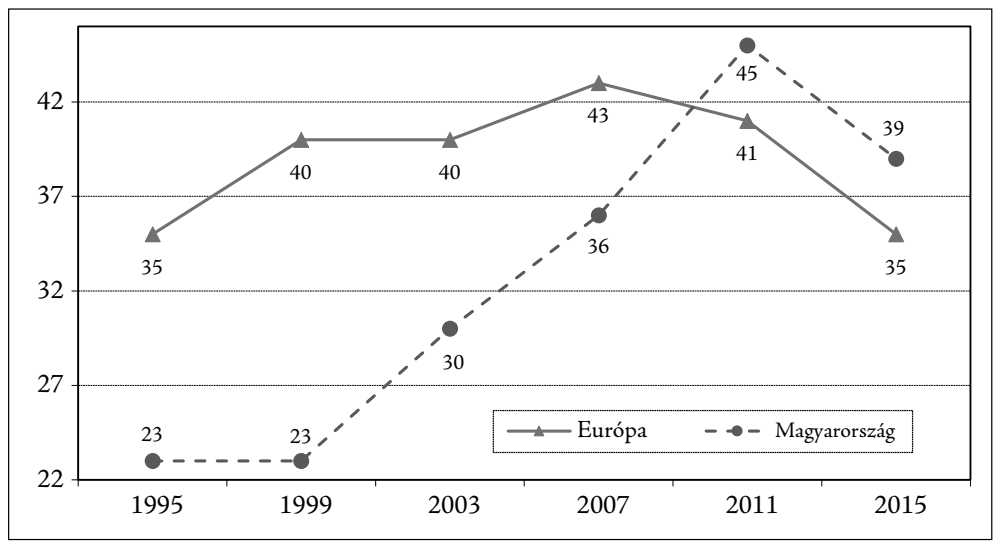

5. ábra: Az előző havi nagyivás arányának változása Magyarországon és az európai átlag 1995-2015 (valamennyi adatfelvételben részt vevő országok adatai) (Saját szerkesztés ESPAD 2015 alapján)

2 Előre összekeverten árusított alkoholtartalmú üdítőital 
A kilencvenes években a nagyivás alig volt jellemző a magyar fiatalokra. 1999-2011 között azonban közel kétszeresére nött a megelöző hónapban legalább egyszer nagyivók aránya. Más mutatókhoz hasonlóan, a trendváltás itt is később következett be nálunk, mint sok más európai országban.

A nagyivás trendje a fiúknál és a lányoknál is megváltozott. És míg az alkoholfogyasztás több más mutatója arra utal, hogy a nemek közötti különbségek nem jelentősek, addig a nagyivás már egyértelmủen a fiúkat jellemzi inkább.

\section{Egyéb drogok}

A tiltott szereket ${ }^{3}$ valaha kipróbálók aránya Európa egészében közel megduplázódott 1995 és 2003 között. A 2003. évi csúcspont után enyhe csökkenés, majd stabilizálódás következett be. Az utolsó adatfelvétel eredményei szerint Európa 16 éveseinek 18\%-a próbált már ki valamilyen tiltott szert az élete során, amely arány még mindig jelentősen meghaladja az 1995. évi adatokat. A tiltott szerfogyasztásban és így a trendek alakulásában is meghatározó a kannabisz fogyasztása valamennyi európai országban. A rendszerváltó országok többségében a tiltott szerek fogyasztása kisebb elterjedtségű volt az időszak kezdetén, majd a növekedés nagyobb mértékű volt és tovább is tartott, mint Nyugat-Európa számos országában. A tiltott szerek és a kannabisz használata is a fuúk körében elterjedtebb volt, mint a lányok között a vizsgált időszak egészében, viszont az elmúlt évek javuló tendenciája elsősorban a fiúk fogyasztásában bekövetkezett visszaesésnek köszönhetö (The ESPAD Group 2016).

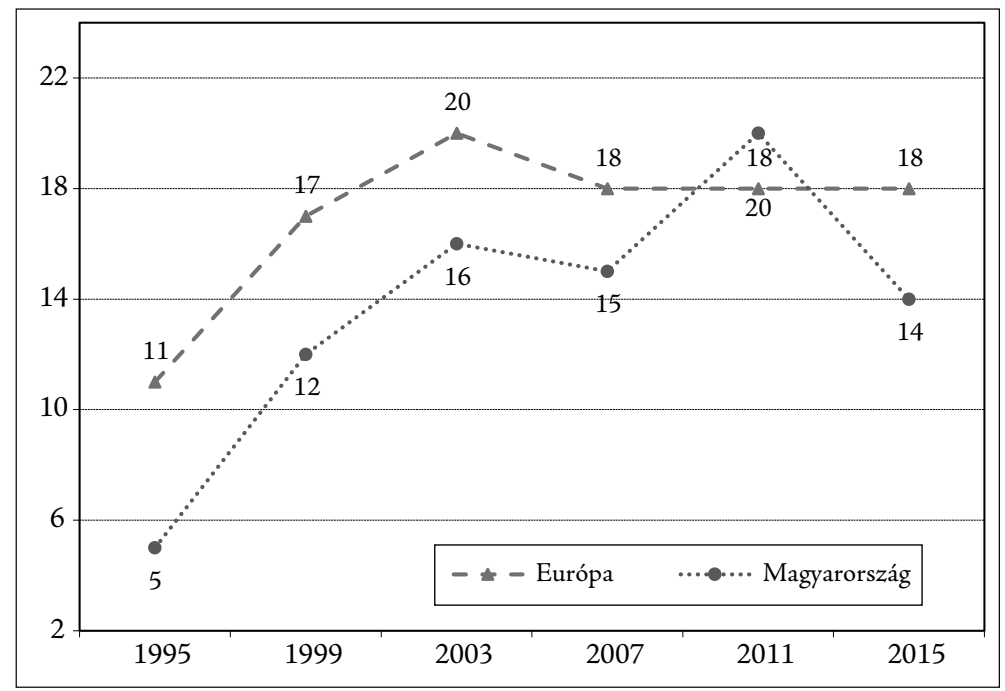

6. ábra: A tiltott szereket valaha kipróbálók arányának változása Magyarországon és az európai átlag 1995-2015 (valamennyi adatfelvételben résztvevő országok adatai)

(Saját szerkesztés ESPAD 2015 alapján)

Tiltott szerek közé az ESPAD-ban kezdetektől megkérdezett, és valamennyi ESPAD-beszámolóban tiltott szerek között szereplő drogokat soroltuk: marihuána/hasis, ecstasy, amfetaminok, LSD vagy más hallucinogének, crack, kokain, heroin. 
A z ESPAD kezdetén, 1995-ben Magyarországon a tiltott szereket valaha kipróbálók aránya alig fele volt az európai átlagnak. A fogyasztás terjedése nagyobb ütemü volt és tovább tartott, mint Európa egészében. 1995-2011 között Magyarországon megnégyszerezödött a tiltott szereket valaha kipróbálók aránya a 16 évesek körében. Bár e tekintetben soha nem tartoztunk Európa vezető országai közé, a 2011. évi magyar kipróbálási arány 4 százalékponttal meghaladta az európai átlagot. A 2015. évi adatok nálunk is a trend kedvező változását jelzik.

A marihuána életprevalencia-értéke 1995 és 2011 között (némi visszaeséssel 2007ben) folyamatosan emelkedett, a kezdeti 4\%-ról 19,4\%-ra nőtt 2011-ben, majd 2015ben 6,3 százalékponttal csökkent az érték. A marihuána esetében az előző hónapban fogyasztók aránya is csökkent 2011 és 2015 között. A nyugtatók/altatók orvosi javaslat nélkül és az alkohol gyógyszerrel való fogyasztása, valamint a szipuzás, a maribuánát követö legelterjedtebben használt szerek voltak 1995 és 2015 között. Az összes többi szer életprevalencia-értéke viszonylag alacsony szinten volt a vizsgált időszakban. 2011 és 2015 között minden szer esetében csökkenés volt megfigyelhetö. A dizájner drogok ${ }^{4}$ elterjedtségét 2015-ben vizsgáltuk először, így ezek változásáról egyelőre nincs információnk. Mindenképpen figyelemre méltónak tartjuk, hogy 2015-ben a magyar 16 éves fiatalok körében az életprevalencia-értékek alapján a második legelterjedtebb szerfogyasztási formává a szintetikus kannabinoidok fogyasztása vált. Ugyanakkor a 16 évesekre vonatkozó európai

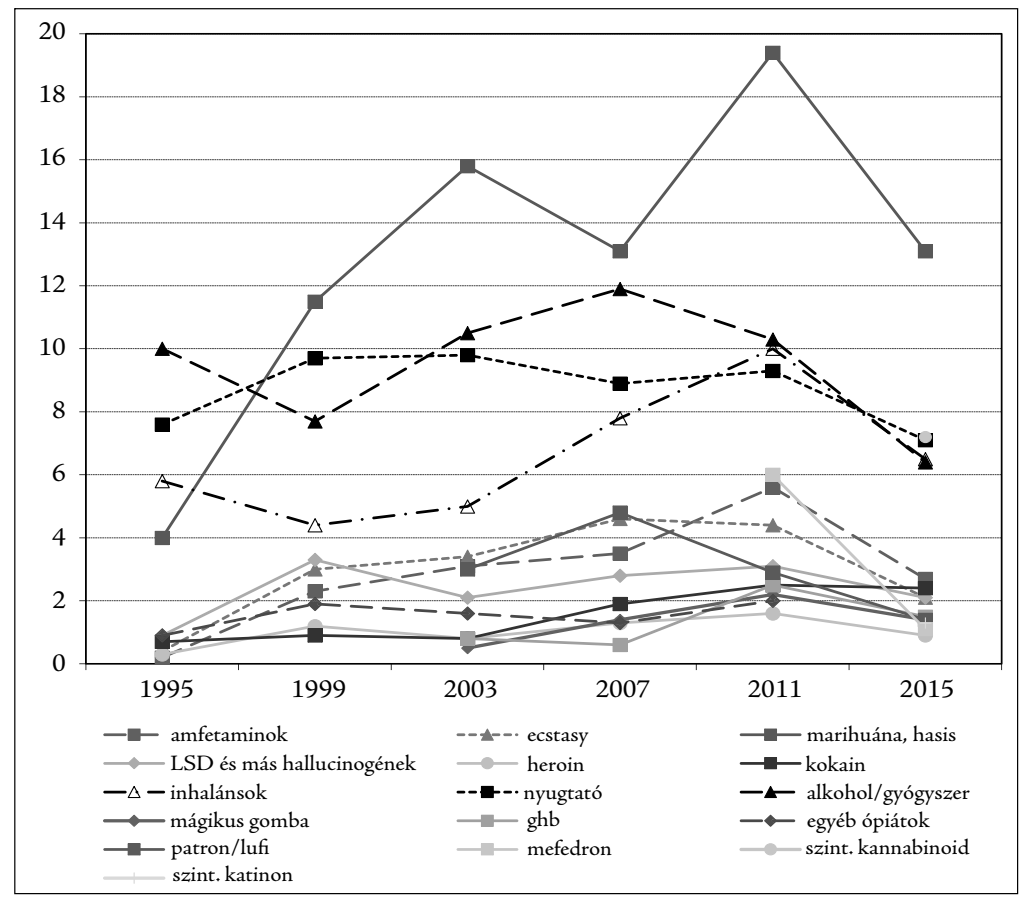

7. ábra: Tiltott és legális szerek életprevalencia-értéke 1995 és 2015 között Magyarországon a 16 éves diákok körében (\%)

A dizájner drogok elnevezés a szintetikus kannabinoidok és a szintetikus katinonok használatát foglalja magában. 
adatok alapján a magyar fialok körében a dizájner drogok használata nem kiemelkedően magas és nem kiemelkedően alacsony, az európai átlagnak megfelelöen alakul.

A tiltott szerek, droghasználati célú szerek ${ }^{5}$ és dizájner drogok használata elterjedtebb a fiúk között, a különböző gyógyszerek orvosi recept nélküli használata pedig inkább a lányokra jellemző. A javuló tendencia mindkét nemnél hasonló mértékben következett be (Nyirády 2016).

\section{A főbb társadalmi-demográfiai tényezők kapcsolata a szerfogyasztással}

A társadalmi-demográfiai tényezők hatását a 2015. évi adatfelvétel 9-10. évfolyamosokra vonatkozó adatai alapján mutatjuk be.

Társadalmi-demográfiai változók közül az iskola típusát, az iskola székhelyét, a család lakóhelyét, a család szerkezetét, a szülők iskolai végzettségét, valamint a család szubjektív anyagi helyzetét vizsgáltuk.

A dohányzást a valaha dohányzók, az előző hónapban dohányzók és a napi rendszerességgel dohányzók aránya alapján elemeztük. Az alkoholfogyasztás mutatói közül az előző hónapban fogyasztók, az előző hónapban nagyivók arányát, valamint az utolsó alkalommal elfogyasztott alkohol egy före jutó mennyiségét vizsgáltuk. Az egyéb drogok fogyasztásának föbb mutatóiként a tiltott szerek, valamint az összes egyéb drog ${ }^{6}$ fogyasztásának az életprevalencia-értékét vontuk be az elemzésbe.

\section{Az iskola}

Az iskola típusa a dohányzás és az egyéb drogfogyasztás valamennyi mutatójával szignifikáns kapcsolatot mutat. Az alkoholfogyasztás mutatói közül a nagyivás és a fogyasztott mennyiség különbözik jelentősen iskolatípusok szerint. A gimnáziumban tanuló diákok között kevesebb a dohányzást kipróbáló, az alkalmi dohányzó és a napi rendszerességgel cigarettát szívó. A rendszeres dohányzás is valamivel később kezdődik náluk, mint más iskolákban tanuló társaiknál. A gimnáziumban tanulók körében kisebb arányú a lerészegedés és a nagyivás, és kisebb az egy alkalommal elfogyasztott alkohol mennyisége is. Ebben az iskolatípusban tanulók körében a legkevésbé elterjedt az egyéb drogok különböző típusainak a fogyasztása is. A dohányzás, az alkoholfogyasztás problémásabb formái és az egyéb drogfogyasztás is a legelterjedtebb a szakiskolákban, abol a fiatalok háromnegyede kipróbálta már a cigarettát és közel minden második fiatal napi rendszerességgel dohányzik. $\mathrm{A} z$ itt tanuló diákok 59\%-a számolt be előző havi nagyivásról és kiemelkedően magas az általuk elfogyasztott alkohol egy före jutó mennyisége is. Ebben az iskolatípusban az összes egyéb drog valamelyik fajtáját a megkérdezettek közel egyharmada, ezen belül tiltott szereket 26,2\% próbált ki az élete során.

Az iskola székhelye a dohányzással nem, a lerészegedéssel, az elfogyasztott alkohol mennyiségével és az egyéb drogfogyasztással viszont szignifikáns összefüggést mutat. A nagyivás elterjedtebb a vidéki középiskolákban, viszont az utolsó alkalommal el-

\footnotetext{
Droghasználati célú szerfogyasztásnak tekintjük az „ESPAD-tiltott szereken” kívül a mágikus gomba, GHB, egyéb opiátok (pl. máktea), szerves oldószerek, patron/lufi és a mefedron használatát.

6 Az összes egyéb drog kategóriája tartalmazza a droghasználati célú szereket, a dizájner drogokat és az orvosi recept nélküli nyugtató/altató fogyasztását.
} 
fogyasztott alkohol mennyisége a Budapesten tanuló diákok között magasabb, mint vidéken. Budapesten az egyéb drogok fogyasztása jóval nagyobb mértékü, mint a vidéki középiskolákban. A család lakóhelye a rendszeresebb dohányzásra és az egyéb drogfogyasztásra vonatkozó mutatókkal van szignifikáns kapcsolatban, ennek alapján azonban azt találjuk, hogy a dohányzás a községekben élök között, az egyéb drogok fogyasztása pedig a fövárosban élök között a legelterjedtebb. Az alkoholfogyasztást nem befolyásolja a család lakóhelye.

\section{A család}

Az eddig készült valamennyi ESPAD-vizsgálatban azt tapasztaltuk, hogy a szerfogyasztás minden formája stabilan szoros kapcsolatban van a családszerkezettel. Azok a fiatalok, akiket mindkét édes szülő együtt nevel, sokkal kisebb arányban próbálják ki a cigarettát, kisebb közöttük a havi vagy napi rendszerességgel dohányzók aránya. Közöttük ritkább a nagyivás, a lerészegedés, alacsonyabb a fogyasztott alkohol mennyisége és még az elöző hónapban ivók aránya is kisebb. Azok a fiatalok, akik mindkét édes szülővel együtt élnek, lényegesen kevésbé fogyasztanak bármilyen drogot, mint a mozaikcsaládban vagy csonka családban élő társaik. Azok a diákok, akiknek a nevelésében nem vesz részt édes szülö (a diákok 7,2\%-a tartozik ebbe a csoportba) a legveszélyeztetettebbek közé tartoznak. Ebben a csoportban a megkérdezettek fele dohányzott az előző hónapban és 40,6\% napi rendszerességgel dohányzik. A nagyivás és az egy alkalommal elfogyasztott alkohol mennyisége is az édes szülő nélkül nevelkedő fiatalok között a legnagyobb arányú. Ugyanakkor az előző hónapban alkoholt fogyasztók aránya náluk a legkisebb. Ennek alapján azt valószínüsítjük, hogy ezek a diákok egyrészt ritkábban isznak a társaiknál, de amikor alkoholt fogyasztanak, az mértéktelenebb formát ölt, mint a többieknél. Az édesszülö nélkül nevelkedök körében kétszer akkora $(30,4 \%)$ a tiltott szereket kipróbálók aránya, mint a teljes családban nevelkedők között. A mozaikcsaládban vagy egyszülős családban élők szintén nagyobb valószínűséggel próbálnak ki egyéb drogokat, mint a teljes családban élők.

Az apa és az anya iskolai végzettsége szintén szignifikáns kapcsolatban van a dohányzással, ugyanakkor nem mutatott egyértelmü összefüggést a fiatalok alkoholfogyasztási szokásaival. Hasonlóan, nem egyértelmü a különbség az egyéb drogok fogyasztása tekintetében. A magasabb iskolai végzettségü szülők gyerekei között kevesebb az alkalmi és a rendszeres dohányzó, és ha dohányoznak, akkor is későbbi életkorban kezdik el a rendszeres dohányzást, mint a többiek. Minél alacsonyabb a szülö iskolai végzettsége, annál elterjedtebb a dohányzás a gyerekek között. Az alkoholfogyasztással kapcsolatos eredmények azt mutatják, hogy az anya iskolai végzettsége valamennyi vizsgált mutatóval, az apa iskolai végzettsége pedig az elöző hónapban alkoholt fogyasztók arányával, a nagyivással és a fogyasztott menynyiséggel is szignifikáns kapcsolatban van. Bár az előző hónapban alkoholt fogyasztók aránya a legalacsonyabb iskolai végzettségű szülők gyerekeinél, valamint a szüleik iskolai végzettségét nem ismerők között a legalacsonyabb, a problémásabb alkoholfogyasztásra utaló mutatók a magasabb iskolai végzettségű szülők gyerekeinél kedvezőbbek, azaz a felsőfokú végzettségü szülök gyerekeinél ritkábban fordul elö nagyivás, és kisebb az elfogyasztott mennyiség is, mint a középfokú vagy ennél alacsonyabb végzettségü szülök gyerekeinél. A korábbi adatfelvételek során azt tapasztaltuk, hogy azok a diákok, akik nem ismerik szüleik iskolai végzettségét (feltehetően nincs, vagy csak gyenge kapcsolat füzi őket a szülőkhöz) a többiekhez képest problémásabb alkoholfogyasztók voltak. A 2015. évi adatok alapján 
azt látjuk, hogy a szüleiket nem ismerök alkobolmutatói kedvezöbbek, mint az alacsonyabb iskolai végzettségü szülök gyermekeié.

Az egyéb drogok fogyasztása és a tiltott szer fogyasztás is hasonló mértékben elterjedt bármilyen végzettségü apa esetén. Az anya iskolai végzettsége szintén nem mutat egyértelmü kapcsolatot a fiatalok egyéb drogfogyasztásával. Csupán az összes egyéb drog fogyasztásánál találtunk enyhe kapcsolatot, amely arra utal, hogy az alacsonyabb iskolai végzettségü anyák gyerekeinél valamelyest elterjedtebb az egyéb drogok fogyasztása, mint a felsőfokú végzettségűeknél.

Hasonló irányú kapcsolatot mutat a szubjektív anyagi helyzet is: bár a család anyagi helyzetét átlagosnak vagy átlag felettinek tartók dohányzási szokása nem különbözik jelentősen, azok a diákok, akik a családjuk anyagi belyzetét átlag alattinak itélték, nagyobb arányban dohányoznak alkalmilag és rendszeresen, valamint korábban is kezdik el a rendszeres dohányzást, mint a többiek. Hasonló tendenciák figyelhetők meg az alkoholfogyasztás és a szubjektív anyagi helyzet között: az átlagos vagy az átlagnál valamivel jobb anyagi belyzetben lévö fiatalok között a legritkább a nagyivás, és ők fogyasztják el a legkisebb mennyiséget is. Az átlag alatti anyagi helyzetben élők körében a legnagyobb az egy alkalommal elfogyasztott mennyiség, viszont a legjobb anyagi helyzetben élők között a legelterjedtebb a nagyivás. A család szubjektív, a megkérdezett diák által érzékelt, anyagi helyzete az egyéb drogfogyasztással is hasonló kapcsolatot mutat: a család anyagi belyzetét átlag alattinak érzékelö diákok körében az összes egyéb drogfogyasztás és a tiltott drogok fogyasztása is elterjedtebb, mint az átlagos vagy annál jobb anyagi belyzetüek között.

A trendekben bekövetkezett kedvezö változások a dohányzás esetében minden társadalmi csoportban megfigyelhetök és hasonló mértéküek voltak. A javuló tendenciák az alkoholfogyasztás föbb mutatói esetében is megtalálhatóak minden vizsgált társadalmi csoportban. Ugyanakkor a dohányzástól eltérően a javulás különböző mértékű volt: nagyobb arányú a javulás a gimnáziumban tanuló, fơvárosban élö, felsőfokú végzettségü apával rendelkezö diákoknál. A tiltott szerek és droghasználati célú szerek fogyasztásában bekövetkezett csökkenés szintén minden társadalmi csoportban megfigyelhető, különösen jelentős mértékü volt azonban a vidéki iskolákban, ahol harmadával estek vissza az életprevalencia-értékek a korábbi adatokhoz képest. A budapesti iskolákban a csökkenés kisebb mértékü, körülbelül $20 \%$-os.

\section{Egyéb rizikótényezők}

A továbbiakban néhány egyéb, a fiatalok fogyasztási szokásait befolyásoló tényező hatását vizsgáljuk az előző havi dohányzás, alkoholfogyasztás, nagyivás, valamint az eddigi életben történt tiltott és összes egyéb drogfogyasztás gyakoriságának alakulására.

A vizsgált változók:

Iskolai lógás napjainak száma az előző hónapban. Ezt a mutatót az ESPAD-kutatások kezdetétől az iskolához való kötödés biánya, illetve a problémás viselkedés indikátoraként használtuk. A mutató 1 és 6 közötti értéket vehet fel, ahol 1 = nem hiányzott, $6=7$ vagy több napot hiányzott.

A szülökhöz és a barátokhoz füzödö viszonnyal való elégedetlenség mértéke. A családi élet és a baráti kapcsolatok minőségét vizsgáltuk ezzel a mutatóval. Egy ötfokú skálán mértük az apához, az anyához és a barátokhoz füződö viszonnyal való elégedettséget ( 1 = nagyon elégedett, 5 = egyáltalán nem elégedett). 
ELEKES ZSUZSANNA: A SZERFOGYASZTÁS RIZIKÓTÉNYEZŐI KÖZÉPISKOLÁSOK KÖRÉBEN

1. táblázat: A dohányzás főbb mutatói társadalmi változók szerint a 9-10. évfolyamon

\begin{tabular}{|c|c|c|c|}
\hline & $\begin{array}{l}\text { Dohányzott az } \\
\text { életben (\%) }\end{array}$ & $\begin{array}{c}\text { Dohányzott az } \\
\text { előző hónapban (\%) }\end{array}$ & $\begin{array}{c}\text { Napi dohányzó } \\
(\%)\end{array}$ \\
\hline \multicolumn{4}{|l|}{$\mathrm{A} z$ iskola típusa ${ }^{* *}$} \\
\hline Gimnázium & 52,3 & 23,6 & 11 \\
\hline Szakközépiskola & 66,1 & 37 & 25,5 \\
\hline Szakiskola & 75 & 53 & 45,5 \\
\hline \multicolumn{4}{|l|}{ Az iskola székhelye } \\
\hline Budapest & 60,8 & 33,8 & 22 \\
\hline Vidék & 62,8 & 35,9 & 25,1 \\
\hline \multicolumn{4}{|l|}{ Lakóhely } \\
\hline Budapest & 60,5 & $34,9^{*}$ & $24,5^{\star *}$ \\
\hline Város & 61,5 & $32,9^{*}$ & $20,9^{\star *}$ \\
\hline Község & 63,1 & $37,1^{*}$ & $26,8^{\star *}$ \\
\hline \multicolumn{4}{|l|}{ Családszerkezet $^{\star *}$} \\
\hline Teljes család & 58,3 & 30,7 & 19,4 \\
\hline Mozaikcsalád & 68,2 & 42,5 & 30 \\
\hline Csonka család & 68,3 & 40,9 & 30,6 \\
\hline Nincs édes szülő & 72,7 & 49,4 & 40,6 \\
\hline \multicolumn{4}{|l|}{ Apa iskolai végzettsége ${ }^{* *}$} \\
\hline Kevesebb mint érettségi & 65,8 & 39,1 & 28,9 \\
\hline Érettségi & 62,5 & 34,4 & 21,8 \\
\hline Felsőfok & 54,7 & 26,7 & 14 \\
\hline Nem tudja, nincs apja & 62 & 37,3 & 28,8 \\
\hline \multicolumn{4}{|l|}{ Anya iskolai végzettsége ${ }^{* *}$} \\
\hline Kevesebb mint érettségi & 66,4 & 40 & 30,5 \\
\hline Érettségi & 63,7 & 35,3 & 23,2 \\
\hline Felsőfok & 54,5 & 27,6 & 14,9 \\
\hline Nincs anya, nem tudja & 62 & 35,7 & 26,1 \\
\hline \multicolumn{4}{|l|}{ Szubjektív anyagi helyzet ${ }^{*}$} \\
\hline $\begin{array}{l}\text { Legjobb vagy sokkal jobb az } \\
\text { átlagnál }\end{array}$ & 62,1 & 36 & 23,8 \\
\hline $\begin{array}{l}\text { Átlagos vagy valamivel jobb az } \\
\text { átlagnál }\end{array}$ & 61,5 & 34 & 23,3 \\
\hline Átlag alatti & 68,6 & 40,8 & 29,3 \\
\hline Összesen & 62,5 & 35,5 & 24,4 \\
\hline$N$ & 4152 & 2361 & 1621 \\
\hline
\end{tabular}


2. táblázat: Az alkoholfogyasztás főbb mutatói társadalmi változók szerint a 9-10. évfolyamon

\begin{tabular}{|c|c|c|c|}
\hline & $\begin{array}{l}\text { Ivott az előző } \\
\text { hónapban (\%) }\end{array}$ & $\begin{array}{l}\text { Volt nagyivás az } \\
\text { előző hónapban } \\
(\%)\end{array}$ & $\begin{array}{l}\text { Utolsó fogyasztás } \\
\text { átlagos mennyi- } \\
\text { sége ( } \mathrm{ml} / \text { fó) }\end{array}$ \\
\hline \multicolumn{4}{|l|}{$\mathrm{Az}$ iskola típusa ${ }^{* *}$} \\
\hline Gimnázium & 59,4 & $37,7^{* *}$ & $69,3^{* *}$ \\
\hline Szakközépiskola & 62,5 & $45,8^{* *}$ & $81,5^{* *}$ \\
\hline Szakiskola & 61,2 & $59,0^{* *}$ & $95,8^{* *}$ \\
\hline \multicolumn{4}{|l|}{$\mathrm{Az}$ iskola székhelye } \\
\hline Budapest & 60,1 & $41,4^{* *}$ & $79,7^{* *}$ \\
\hline Vidék & 61,0 & $46,7^{* *}$ & $79,2^{* *}$ \\
\hline \multicolumn{4}{|l|}{ Lakóhely } \\
\hline Budapest & 60,6 & 44,2 & 78,9 \\
\hline Város & 62,3 & 44,3 & 78,7 \\
\hline Község & 60,1 & 47,1 & 79,8 \\
\hline \multicolumn{4}{|l|}{ Családszerkezet ${ }^{* *}$} \\
\hline Teljes család & $59,8^{*}$ & $42,9^{* *}$ & $76,3^{* *}$ \\
\hline Mozaikcsalád & $63,8^{*}$ & $49,6^{* *}$ & $82,6^{* *}$ \\
\hline Csonka család & $63,0^{*}$ & $48,4^{* *}$ & $84,0^{* *}$ \\
\hline Nincs édes szülő & $59,4^{*}$ & $54,4^{* *}$ & $92,9^{* *}$ \\
\hline \multicolumn{4}{|l|}{ Apa iskolai végzettsége ${ }^{* *}$} \\
\hline Kevesebb mint érettségi & $59,1^{*}$ & $47,3^{* *}$ & $81,3^{* *}$ \\
\hline Érettségi & $63,6^{*}$ & $48,2^{* *}$ & $81,3^{* *}$ \\
\hline Felsőfok & $62,9^{*}$ & $38,9^{* *}$ & $73,0^{* *}$ \\
\hline Nem tudja, nincs apja & $55,9^{*}$ & $42,9^{* *}$ & $75,6^{* *}$ \\
\hline \multicolumn{4}{|l|}{ Anya iskolai végzettsége ${ }^{* *}$} \\
\hline Kevesebb mint érettségi & $57,9^{* *}$ & $48,6^{* *}$ & $80,4^{* *}$ \\
\hline Érettségi & $63,4^{\star *}$ & $46,9^{\star *}$ & $82,8^{* *}$ \\
\hline Felsőfok & $62,6^{* *}$ & $39,5^{* *}$ & $73,7^{* *}$ \\
\hline Nincs anya, nem tudja & $53,9^{\star *}$ & $39,9^{* *}$ & $77,0^{\star *}$ \\
\hline \multicolumn{4}{|l|}{ Szubjektív anyagi helyzet ${ }^{*}$} \\
\hline $\begin{array}{l}\text { Legjobb vagy sokkal jobb az } \\
\text { átlagnál }\end{array}$ & 63,3 & $50,8^{\star *}$ & $86,1^{* *}$ \\
\hline $\begin{array}{l}\text { Átlagos vagy valamivel jobb az } \\
\text { átlagnál }\end{array}$ & 60,1 & $43,6^{* *}$ & $76,3^{* *}$ \\
\hline Átlag alatti & 60,9 & $45,4^{* *}$ & $91,2^{* *}$ \\
\hline Összesen & 60,8 & 45,6 & 79,7 \\
\hline$N$ & 4013 & 3038 & \\
\hline
\end{tabular}

${ }^{*} p<0,05,{ }^{* *} p=0,000$ 
3. táblázat: Az egyéb drogfogyasztás főbb mutatói társadalmi változók szerint a 9-10. évfolyamon

\begin{tabular}{|c|c|c|}
\hline & $\begin{array}{c}\text { Ivott az előző hónapban } \\
(\%)\end{array}$ & $\begin{array}{l}\text { Volt nagyivás az előző } \\
\text { hónapban (\%) }\end{array}$ \\
\hline \multicolumn{3}{|l|}{$\mathrm{Az}$ iskola típusa ${ }^{* *}$} \\
\hline Gimnázium & 15,0 & 23,2 \\
\hline Szakközépiskola & 20,3 & 28,9 \\
\hline Szakiskola & 26,2 & 32,3 \\
\hline \multicolumn{3}{|l|}{$\mathrm{A} z$ iskola székhelye } \\
\hline Budapest & 28,3 & 34,4 \\
\hline Vidék & 17,3 & 25,5 \\
\hline \multicolumn{3}{|l|}{ Lakóhely } \\
\hline Budapest & 25,0 & 32,1 \\
\hline Város & 18,6 & 25,9 \\
\hline Község & 17,3 & 26,1 \\
\hline \multicolumn{3}{|l|}{ Családszerkezet $^{\star *}$} \\
\hline Teljes család & 15,6 & 23,7 \\
\hline Mozaikcsalád & 23,1 & 32,3 \\
\hline Csonka család & 26,1 & 32,3 \\
\hline Nincs édes szülő & 30,4 & 36,4 \\
\hline \multicolumn{3}{|l|}{ Apa iskolai végzettsége ${ }^{* *}$} \\
\hline Kevesebb mint érettségi & 19,4 & 27,4 \\
\hline Érettségi & 19,9 & 29,1 \\
\hline Felsőfok & 18,5 & 24,9 \\
\hline Nem tudja, nincs apja & 18,5 & 24,7 \\
\hline \multicolumn{3}{|l|}{ Anya iskolai végzettsége ${ }^{\star *}$} \\
\hline Kevesebb mint érettségi & 19,0 & $27,5^{\star}$ \\
\hline Érettségi & 20,9 & $29,8^{*}$ \\
\hline Felsőfok & 17,6 & $23,7^{*}$ \\
\hline Nincs anya, nem tudja & 18,6 & $24,7^{*}$ \\
\hline \multicolumn{3}{|l|}{ Szubjektív anyagi helyzet* } \\
\hline $\begin{array}{l}\text { Legjobb vagy sokkal jobb az } \\
\text { átlagnál }\end{array}$ & 20,4 & 27,0 \\
\hline $\begin{array}{l}\text { Átlagos vagy valamivel jobb az } \\
\text { átlagnál }\end{array}$ & 18,1 & 26,1 \\
\hline Átlag alatti & 26,7 & 34,7 \\
\hline Összesen & 19,5 & 27,3 \\
\hline$N$ & 1282 & 1728 \\
\hline
\end{tabular}

${ }^{*} p<0,05,{ }^{* *} p=0,000$ 
A szülői kontroll hiányát a „Tudják-e a szüleid, hol töltöd a szombat estéidet?” kérdéssel vizsgáltuk 4 fokú skálán ( 1 = mindig tudják, 4 = általában nem tudják).

A szabadidő eltöltésére vonatkozó kérdéseket faktoranalizis során redukáltuk és négy faktort alakítottunk ki: elmenös szabadidö, könyvolvasás és egyéb hobbi, sport, internethasználat. A kérdések az egyes tevékenységek gyakoriságát ötfokú skálán mérték ( $1=$ soha, 5 = majdnem minden nap).

Az önbecsülést a Rosenberg-féle önbecsülésskálán mértük. Ez a skála egy 10 itemből álló kérdéssorozat, amely 4 fokú skálán méri a különféle, önbecsüléssel kapcsolatos állításokkal való egyetértés mértékét (Kokkevi-Fotiou 2009). Az önbecsülésskála kérdéseiből - a pozitív és negatív állítások egyirányba fordítása után - önbecsülési biány indexet képeztünk, amely 10 és 40 közötti értéket vehet fel, és amely indexnél az alacsonyabb érték az önbecsülést, a magasabb érték pedig az önbecsülés hiányát jelezte.

A depresszió mértékét a korábbi ESPAD-vizsgálatokhoz hasonlóan, a Weissmannféle depresszióskálán vizsgáltuk. Ez a skála hat itemből áll, és különféle depressziós tünetek előfordulását kérdezi a megelőző hét napra vonatkozóan (Kokkevi-Fotiou 2009). A depresszió-skála értékét az egyes kérdésekre adott válaszok alapján indexeltük. Ennek megfelelően a skála 6-24 közötti értéket vehet fel, ahol a kisebb értékek a tünetek előfordulásának a ritkáságát, a nagyobb értékek pedig a gyakoribb előfordulást jelzik.

A fenti mutatók és a különböző szerfogyasztási formák gyakoriságának kapcsolatát Spearman-féle korrelációs együtthatóval vizsgáltuk. Az eredményeket a 4. táblázat foglalja össze:

A legtöbb vizsgált mutató szignifikáns kapcsolatban van az elemzett rizikó-magatartásokkal. Az elmenös szabadidös tevékenységek (diszkó, buli, barátokkal való mászkálás) gyakorisága a dohányzás, az alkoholfogyasztás és az egyéb drogfogyasztás mutatóival is az egyik legszorosabb kapcsolatot mutatja, de kiemelkedően magas a korrelációs együttható értéke az előző havi alkoholfogyasztás és nagyivás esetében is. Az iskolai lógás szintén fontos jelzésnek látszik a rizikó-magatartások szempontjából: a lógás miatt hiányzott napok száma valamennyi fogyasztási formával erős pozitív kapcsolatot mutat. Szoros öszszefüggést találunk a szülöi kontroll biánya, valamint a dohányzás, nagyivás és az egyéb drogfogyasztás gyakorisága között. Az apához füződő viszonnyal való elégedetlenséggel az előző havi dohányzás és az összes egyéb drogfogyasztás gyakorisága mutat szorosabb kapcsolatot. Az anyához füződő viszonnyal való elégedetlenség az egyéb drogfogyasztásban játszik jelentősebb szerepet. A szülőkétől eltérő irányú kapcsolatot találunk a barátokhoz füződő viszonnyal való elégedetlenség esetében: minél elégedettebbek a fiatalok a barátaikhoz füzödö viszonnyal, annál nagyobb gyakoriságú szerfogyasztás jellemzi öket. Érdemes felfigyelni arra, hogy negatív kapcsolatot a különböző szerfogyasztási formák a „nem elmenős” szabadidő eltöltési formákkal jelzik. Azaz a gyakoribb sportolás, olvasás vagy más hobbitevékenység, sőt a szabadidős internethasználat nagyobb gyakorisága is mérsékeltebb szerfogyasztási gyakorisággal társul. Végül a fiatalok lelkiállapotát mérő mutatók közül a depresszió mértéke jelez kapcsolatot a dohányzás, alkoholfogyasztás és egyéb drogfogyasztás gyakoriságával. Azaz, a depressziós tünetek nagyobb mértékü elöfordulása nagyobb gyakoriságú szerfogyasztással jár együtt.

A társadalmi-demográfiai tényezők és az egyéb rizikótényezők önálló hatásának vizsgálatára további elemzéseket végeztünk. Ennek során klaszterelemzéssel elkülönítettünk egy kifejezetten problémás szerhasználónak tekinthetö csoportot. Ez a csoport a teljes minta 
4. táblázat: A szerfogyasztás különböző mutatóinak gyakorisága, valamint az egyéb rizikómutatók közötti kapcsolatot kifejező Spearman-féle korrelációs együttható értéke

\begin{tabular}{|c|c|c|c|c|c|}
\hline Mutató & $\begin{array}{l}\text { Előző havi } \\
\text { dohányzás } \\
\text { gyakorisága }\end{array}$ & $\begin{array}{c}\text { Előző havi } \\
\text { alkoholfogyasztás } \\
\text { gyakorisága }\end{array}$ & $\begin{array}{l}\text { Előző havi } \\
\text { nagyivás } \\
\text { gyakorisága }\end{array}$ & $\begin{array}{l}\text { Tiltott drog } \\
\text { gyakorisága } \\
\text { az életben }\end{array}$ & $\begin{array}{l}\text { Összes egyéb } \\
\text { drog gyakorisá- } \\
\text { ga az életben }\end{array}$ \\
\hline & \multicolumn{5}{|c|}{ Korrelációs együttható } \\
\hline $\begin{array}{l}\text { Az előző hónap- } \\
\text { ban az iskolából } \\
\text { hiányzott napok } \\
\text { száma lógás miatt }\end{array}$ & $0,257^{* *}$ & $0,169^{* *}$ & $0,218^{* *}$ & $0,259^{* *}$ & $0,251^{* *}$ \\
\hline $\begin{array}{l}\text { Elégedetlenség } \\
\text { a barátokhoz } \\
\text { füződő viszonnyal }\end{array}$ & $-0,036^{* *}$ & $-0,053^{* *}$ & $-0,070^{* *}$ & $0,018^{\star *}$ & $0,052^{* *}$ \\
\hline $\begin{array}{l}\text { Elégedetlenség az } \\
\text { anyához füződő } \\
\text { viszonnyal }\end{array}$ & $0,081^{* *}$ & $0,041^{* *}$ & $0,027^{\star *}$ & $0,118^{* *}$ & $0,126^{* *}$ \\
\hline $\begin{array}{l}\text { Elégedetlenség az } \\
\text { apához füződő } \\
\text { viszonnyal }\end{array}$ & $0,129^{* *}$ & $0,037^{* *}$ & $0,048^{\star *}$ & $0,084^{* *}$ & $0,156^{* *}$ \\
\hline $\begin{array}{l}\text { Szülői kontroll } \\
\text { hiánya }\end{array}$ & $0,228^{\star *}$ & $-0,053^{* *}$ & $0,257^{* *}$ & $0,225^{* *}$ & $0,228^{* *}$ \\
\hline $\begin{array}{l}\text { Elmenős } \\
\text { szabadidős } \\
\text { tevékenységek } \\
\text { gyakorisága }\end{array}$ & $0,299^{* *}$ & $0,422^{* *}$ & $0,401^{\star *}$ & $0,255^{* *}$ & $0,249^{* *}$ \\
\hline $\begin{array}{l}\text { Könyv/hobbi- } \\
\text { tevékenységek } \\
\text { gyakorisága }\end{array}$ & $-0,170^{\star *}$ & $-0,140^{* *}$ & $-0,199^{* *}$ & $-0,116^{\star *}$ & $-0,086^{\star *}$ \\
\hline Sport gyakorisága & $-0,174^{* *}$ & $-0,060^{\star *}$ & $-0,080^{\star *}$ & $-0,96^{* *}$ & $-0,129^{\star *}$ \\
\hline $\begin{array}{l}\text { Szabadidős } \\
\text { internethasználat } \\
\text { gyakorisága }\end{array}$ & $-0,111^{* *}$ & $-0,128$ & $-0,160^{* *}$ & $-0,088^{* *}$ & $-0,058^{\star *}$ \\
\hline $\begin{array}{l}\text { Depresszió } \\
\text { mértéke }\end{array}$ & $0,109^{\star *}$ & $0,100^{* *}$ & $0,082^{* *}$ & $0,079^{* *}$ & $0,164^{* *}$ \\
\hline $\begin{array}{l}\text { Önbecsülés } \\
\text { hiánya }\end{array}$ & $0,076^{* *}$ & 0,002 & 0,012 & 0,018 & $0,098^{* *}$ \\
\hline
\end{tabular}

${ }^{*} p<0,05,{ }^{* *} p<0,01$

8,7\%-át jelentette. Ebben a csoportban a fiatalok közel háromnegyede napi rendszerességgel dohányzik, $80 \%$ számolt be előző havi nagyivásról, több mint kétharmaduk volt részeg a megelőző hónapban. Valamilyen egyéb drogot mindenki kipróbált közülük, többségük használt már valamilyen tiltott szert és több mint kétharmaduk kipróbált valamilyen dizájner drogot is. Átlag feletti a problémás internet/Facebook/online-játék használók aránya is. Elemzéseink azt mutatták, hogy a problémás használóvá válás esélyét 
növeli az, ha valaki a fövárosban él, szakiskolában vagy szakközépiskolában tanul, kevésbé jó az apjához füzödö viszonya, kisebb az önbecsülése, elöfordulnak depressziós tünetek és inkább az elmenös szabadidö-eltöltési formák jellemzik. Az apa és az anya iskolai végzettségének, a család lakóhelyének és szubjektív anyagi helyzetének az önálló hatását az elemzések nem mutatták ki (Elekes 2016).

\section{Következtetések}

A z ESPAD-kutatások eredményei azt mutatják, hogy a kilencvenes évek második felében a dohányzás, az alkoholfogyasztás és az egyéb drogok fogyasztása is terjedt Európa jelentős részén. A kétezres évek elején a trendek változni látszanak, és számos európai országban csökken vagy stabilizálódik a dohányzás, alkoholfogyasztás és egyéb drogfogyasztás legtöbb mutatója. Magyarországon, a rendszerváltó országok többségéhez hasonlóan, a növekedés tovább tartott, de a trendek az utóbbi években szinte mindenhol a javuló tendenciákat mutatják. A javuló tendenciák ellenére a magyar fiatalok dohányzása és alkoholfogyasztása még mindig magas szinten van nemzetközi összehasonlításban.

A szakirodalom régóta vitatja, hogy kimutatható-e egyértelmű társadalmi különbség a drogfogyasztási szokásokban (Currie et al. 2008; Bjarnasson et al. 2003; Hibell et al. 2004). A magyar eredmények a társadalmi háttér hatását csak a dohányzás esetében igazolják egyértelműen: az alacsonyabb végzettségü, rosszabb anyagi körülmények között élő szülők szakiskolában tanuló gyermekei érintettek inkább. Az alkoholfogyasztás esetében kevésbé egyértelmű, de a korábbi évekhez képest határozottabb társadalmi különbségek rajzolódnak ki. Elsősorban a magasabb iskolai végzettségű szülők gimnáziumban tanuló gyermekei körében tünik mérsékeltebbnek az alkoholfogyasztás. A tiltott szerek esetében változatlanul nem mutathatók ki határozott társadalmi különbségek a drogokat fogyasztók és nem fogyasztók között. Ugyanakkor a tiltott és legális szerhasználat kialakulásában is meghatározónak látszanak a családon belüli és a barátokhoz füzödö kapcsolatok, valamint a szabadidö eltöltésének a módja.

\section{IRODALOM}

Bjarnasson, T., Andersson, B., Choquet, M., Elekes, Zs., Morgan, M. \& Rapinett, G. (2003) Alcohol, Culture, Family Stucture and Adolescent Alcohol Use: Multi-level Modeling of Frequency of Heavy Drinking among 15-16 Year Old Students in Eleven European Countries. Journal of Studies on Alcobol, Vol. 64. pp. 200-208.

Currie, C., Gabhainn, S., Godeau, E., Roberts, C., Smith, R., Currie, D., Pichet, W., Richter, M., Morgan, A. \& Barnekow, V. (2008, eds) Inequalities in Young People's Health. HBSC International Report from the 2005/2006 Survey. Geneva, WHO.

Elekes Zs. (2016, ed.) Európai iskolavizsgálat az alkohol-és egyéb drogfogyasztási szokásokról - 2015. Magyarországi eredmények. Budapest, Budapesti Corvinus Egyetem Szociológia és Társadalompolitika Intézet.

Hibell, B., Andersson, B., Bjarnasson, T., Ahlström, S., Balakireva, O., Kokkevi, A. \& Morgan, M. (2004) The ESPAD Report 2003. Alcohol and Other Drug Use among Students in 35 European Countries. Stockholm, CAN, Council of Europe. 
Hibell, B., Guttormsson, U., Ahlström, S., Balakireva, O., Bjarnason, T., Konkevi, A. \& Kraus, L. (2012) The 2011 ESPAD Report. Substance Use Among Students in 36 European Countries. Stockholm. CAN, EMCDDA, Council of Europe.

Kokкevi, A. \& Fotiou, A. (2009) The ESPAD Psychosocial Modul. In: B. Hibell et al.: The 2007 ESPAD Report. Stockholm, CAN EMCDDA, Council of Europe. pp. 172-183.

Nyírády A. (2016) Egyéb drogok, új pszichoaktív szerek. In: Elekes Zs. (ed.) Európai iskolavizsgálat az alkobol-és egyéb drogfogyasztási szokásokról - 2015. Magyarországi eredmények. Budapest, Budapesti Corvinus Egyetem Szociológia és Társadalompolitika Intézet. pp. 57-74.

The ESPAD Group (2016) ESPAD REPORT. Results from the European School Survey Project on Alcohol and Other Drugs. Lisbon, EMCDDA.

A cikk a Creative Commons Attribution 4.0 International License (https://creativecommons.org/licenses/ by/4.0/) feltételei szerint publikált Open Access közlemény, melynek szellemében a cikk bármilyen médiumban szabadon felhasználható, megosztható és újraközölhető, feltéve, hogy az eredeti szerző és a közlés helye, illetve a CC License linkje és az esetlegesen végrehajtott módosítások feltüntetésre kerülnek. (SID_1) 